RAE-IC, Revista de la Asociación Española de Investigación de la Comunicación vol. 8, núm. 16 (2021), 168-194 ISSN 2341-2690

Recibido el 10 de agosto de 2021 DOI: https://doi.org/10.24137/raeic.8.16.9 Aceptado el 16 de octubre de 2021

\title{
Women Journalists and Social Media Activism: An Analysis of the Hashtags \#DeixaElaTrabalhar and \#LasPeriodistasParamos on Instagram
}

Mujeres periodistas y activismo en redes sociales: un análisis de los hashtags \#DeixaElaTrabalhar y \#LasPeriodistasParamos en Instagram

\author{
López-Ortega, Marina \\ Unviersity of Vienna (UNVIE) \\ marina.lop.ortega@gmail.com
}

Noronha, lara

Unviersity of Vienna (UNVIE)

noronhaiara@gmail.com

Forma de citar este artículo:

López-Ortega, M. y Noronha, I. (2021). Women Journalists and Social Media Activism: An Analysis of the Hashtags \#DeixaElaTrabalhar and \#LasPeriodistasParamos on Instagram. RAE-IC, Revista de la Asociación Española de Investigación de la Comunicación, 8(16), 168-194.

https://doi.org/10.24137/raeic.8.16.9

\section{Abstract:}

The social media collective actions through the hashtags \#DeixaElaTrabalhar and \#LasPeriodistasParamos raised problems that women journalists were suffering in both Brazil and Spain. While the representation of feminism has long been studied, less 
attention has been paid to comparative studies and the more personal representation. Focusing on a combination of visual and textual qualitative content analysis, we explore 90 Instagram posts from women journalists within the two hashtags and how they portray themselves in relation to their profession. At the time of writing, Instagram is one of the most popular social networks focused on the publication of audiovisual content. This makes it suitable for the study of online self-representation. The article identifies using the Documentary Image Analysis and the Critical Discourse Analysis the recurrent demands and denunciations regarding journalism gender-related issues and finds common visual vernaculars in \#DeixaElaTrabalhar and \#LasPeriodistasParamos posts. This study makes a comprehensive analysis of how women journalists construct their identity on Instagram images concerning the topics they talk about and the elements they use to insert themselves in the female journalists' collectives and connects it with the theories on feminism and social media activism. The results reported here shed new light on how female journalists take control over their situation and find empowerment, feminism, non-violent protest, and professional/private life to be common points regarding the identity construction in relation to these online groups.

Keywords: gender, journalists, digital activism, hashtag, feminism, Instagram, identity construction, content analysis.

\section{Resumen:}

Las acciones colectivas en las redes sociales a través de los hashtags \#DeixaElaTrabalhar y \#LasPeriodistasParamos plantearon los problemas que sufrían las mujeres periodistas tanto en Brasil como en España. Aunque la representación del feminismo ha sido estudiada durante mucho tiempo, se ha prestado menos atención a los estudios comparativos y a la representación más personal. Centrándonos en una combinación de análisis de contenido cualitativo visual y textual, exploramos 90 posts de Instagram de mujeres periodistas dentro de los dos hashtags y cómo se retratan a sí mismas en relación con su profesión. En el momento de escribir este artículo, Instagram es una de las redes sociales más populares centradas en la publicación de contenidos audiovisuales. Esto la hace idónea para el estudio de la autorrepresentación online. El 
artículo identifica mediante el Análisis de la Imagen Documental y el Análisis Crítico del Discurso las demandas y denuncias recurrentes sobre temas relacionados con el género periodístico y encuentra vernáculos visuales comunes en los posts \#DeixaElaTrabalhar y \#LasPeriodistasParamos. Este estudio hace un análisis exhaustivo de cómo las mujeres periodistas construyen su identidad en las imágenes de Instagram en relación con los temas de los que hablan y los elementos que utilizan para insertarse en los colectivos de mujeres periodistas y lo conecta con las teorías sobre el feminismo y el activismo en las redes sociales. Los resultados aquí expuestos arrojan nueva luz sobre cómo las periodistas toman el control de su situación y encuentran que el empoderamiento, el feminismo, la protesta no violenta y la vida profesional/privada son puntos comunes en la construcción de la identidad en relación con estos grupos online.

Palabras clave: género, periodistas, activismo digital, hashtag, feminismo, Instagram, construcción de la identidad, análisis de contenido.

\section{INTRODUCTION}

After the \#MeToo movement exploded in 2017 and spread widely on social media, the effects of the allegations of sexual harassment of women not only reached journalism but also spread globally (Steiner, 2019). In Spain, female journalists united under the hashtag \#LasPeriodistasParamos to denounce their professional situation (BernalTriviño \& Sanz-Martos, 2020). The group, which originated in connection to the feminist strike on 8 March 2018, became a form of online activism against the discrimination and the precarious situation of women in labour, especially in journalism and communications (Bernal-Triviño \& Sanz-Martos, 2020). Similarly, Brazilian women sports journalists virtually gathered under the hashtag \#DeixaElaTrabalhar which was born from a protest video created by 50 sports journalists (RWB report, 2020) to draw attention to the harassment and discrimination suffered within the field of sports journalism (Ramires, 2020). In both countries, there is evidence that the macho culture of the newsrooms - which several authors in the field have discussed in other regions (Melki \& Mallat, 2019; Ross \& Padovai, 2019; Allan, 2019) - is latent. Examples of this 
are the sexist environment, job insecurity or the wage gap affecting females within the media industry in Spain (Valcarcel, Fernández, and Castro-Martinez 2019), and the need for women journalists in Brazil to prove their professional worth to their bosses and colleagues daily (Ramires, 2020). Moreover, the problems extend to the practice of journalism itself. The coverage of women in the mainstream news media is insignificant, and feminism is often delegitimized, marginalized, and trivialized (Geertsema-Sligh, 2018). Brazilian and Spanish female journalists have used social media platforms to manifest their nonconformity and contribute to the feminist movement (Bernal-Triviño \& Sanz-Martos, 2020; Matos, 2017). Such online collectives can be interpreted as a strategy on the part of female journalists to politicize their personal experiences (Clark, 2014) and to bring about change (Antunovic, 2019).

This study explores how women journalists portray themselves on their Instagram posts concerning the \#DeixaElaTrabalhar and the \#LasPeriodistasParamos collectives. In particular, we strive to identify the denunciations concerning gender-related problems in their profession as well as the visual elements shaping the meaning of the posts and their discourse in relation to the hashtags. First, the intellectual framework explores the theories about stereotypes and the representation of women in the media and the digital sphere as well as the situation of female journalists. Then we draw upon feminism, especially related to digital activism on social media. Finally, we do a qualitative analysis with still images posted by Brazilian and Spanish female journalists using the mentioned hashtags in a time frame between 2018 and 2021.

\section{STEREOTYPES AND THE REPRESENTATION OF WOMEN IN THE MEDIA}

In the academic field, Stuart Hall thickened the debate on representation within cultural studies and defined stereotypes in the cultural narrative: "reduced to a few essentials, fixed in nature by a few simplified characteristics'" (Hall, 2000, p.249). He explains that while the type is fundamental to point out the differences between things, classify and understand the world, the stereotype essentialises the view of a person "to those traits, exaggerating and simplifying them, and fixing them without change or development to eternity" (Hall, 2000, p.258). The media has traditionally been pointed to as a cultural 
agent constructing and/or perpetuating stereotypes, especially concerning women (Geertsema-Sligh, 2018; Kitch, 2015; Ruoho \& Sinikka Torkkola, 2018; Sarikakis \& Nguyen, 2009). Margaretha Geertsema-Sligh (2018) discusses in her work the participation of women journalists in the media industry and the coverage and representation of women in the news. The author describes how women's image and presence are constantly stereotyped, often portraying them as victims, wives, mothers, or even omitted on the news.

Particularly interesting is the process of re-sexualisation of women by the media and the popular culture explained by Rosalind Gill (2003): women have gone from being sexual objects to sexual subjects - "around sexual confidence and autonomy" (p. 103) -in the attempt to create a "new femininity" (p. 103). However, this modern femininity is exclusionary for many women and entails struggles that are hidden. Similarly, Angela McRobbie (2004) notes how "the media has become the key site for defining codes of sexual conduct" (p. 31). She also points at the "simultaneous feminisation" of the media landscape, offering a wide range of products that would provide women with the freedom to decide the kind of life they want - what she calls the "female individualisation" (p. 32).

When Cynthia Carter (2019) talks about the relationship between journalism and gender, she highlights how, traditionally, media have made the distinction between professional male journalism attached to topics like politics, economics, or businesses, and journalism considered of special interest - sometimes not even considered "real" journalism - attached to topics such as lifestyle and females. Carter argues that this process of assigning gender to different forms of journalistic content is problematic and affects the perception of who is allowed to do journalism. Similarly, Suzzane Franks and Lis Howell (2019) argue, when discussing female authority in the news, how attitudes towards women might change if more women are shown in other roles, which would ultimately be the news media's responsibility.

Furthermore, it has been often asserted that female journalists report with different values than men, which might make journalistic content more feminine (Steiner, 2019). 
Far from that idea, Hanitzsch and Hanusch (2012) proved among 18 countries that reporting and role perceptions do not differ in a meaningful way between genders. These results have found much support (Ruoho \& Torkkola, 2018; Steiner, 2019). However, female reporters are continuously destined to cover soft news and distanced specific journalistic fields (Geertsema-Sligh, 2018). The male-dominated culture of newsrooms often disempowers female journalists and claims their lack of seriousness in reporting traditional news. Geertsema-Sligh (2018) notes that "the value of objectivity is, in fact, a white and male point of view" (p. 3). Consequently, not only the image of women journalists promoted by the mainstream media but also their practices as news workers would be affected by the continuation of the traditional stereotypes assigned to females.

\section{FEMINISM AND DIGITAL ACTIVISM ON SOCIAL MEDIA}

To fight against the stereotyped representation of women, we use women empowerment. The empowerment process is a communal and a social one: the person or institution becomes more independent and strong but only through the community (Freire, 2007; Rappaport, 1987). This idea applied to the digital era takes us to the social media realm. Additionally, Rappaport (1987) adds on the social view that it is "a mechanism by which people, organisations, and communities gain mastery over their affairs" (p. 122). Furthermore, he says that the concept involves respectful, caring, and reflective participation in a community group to gain equal access to and control resources (Rappaport, 1995).

Scholars have often explored the use of social media as a platform for protest, activism and empowerment. Langman \& Morris affirm that with the growing use of the internet and the emergence of the so-called internetworking and cyberactivism, it becomes urgent to increase the field of study of social movements so that new associations can be drawn on their social and purposeful nature (2003, p. 14). The internet is a new form of social organization and activism that shares the articulated objectives of old democratic mobilizations, such as suffragism or even civil rights (Langman \& Morris, 2003 , p. 13). The new dynamic between social media platforms to political and 
economical issues, connecting communication interaction and technology (Gisleppie, 2010; 2018a; 2018b; Van Dijck, 2013) made the Collective Action Theory. This phenomenon incorporates new forms of action together with traditional actions, creating a collective identity. The logic of connective action intensifies the possibility of personalization (Bennett \& Segerberg, 2012). Bennett and Segerberg (2012) credit this aspect of the logic of connective action to what they define as personal action-frames, which are formed from two elements: symbolic inclusiveness, which is when large-scale protests use language linked to emotions; technological opening, large-scale connective actions take place on digital platforms, which makes the process more diffuse and broader.

All things considered, political participation becomes individualized and finds in the hashtags the ability to personify mobilizations. The hashtags are marked with the "\#" symbol, which allows indexing of the content, meaning users can follow the speech on topics and see what other users are saying. This enhances the interaction between users, since they can relate to other subjects outside their contact network. Hashtag activism (Clark, 2016; Hopke, 2015; Yang, 2016) occurs when a large number of comments appear in digital media, indexing a word or phrase as a hashtag, always with content of claim and protest. As these comments consist of countless personal stories, they take on a personified narrative form as they are collectively recognized by the audience. Feminist or women's themes appeared in these online movements, bringing up topics that were not talked about in conventional media and creating a virtual space where victims of oppression can coexist together in a space that recognizes their pain and narrative (Dixon, 2014). When aligned with feminist demands, these hashtags are called hashtag feminism (Clark, 2016), and they advance by helping to improve the quality of debate, expanding the voices of marginalized and silenced groups within global feminist movements.

The literature on hashtag feminism investigates the practice of claiming inequality and gender violence that circulates on social media platforms indexed with hashtags. In general, the works focus on how this new form of mobilization is incorporated by feminist movements when perceived as a discursive tactic (Clark, 2016; Barker- 
Plummer, 2017; Shaw, 2016; Khoja-Moolji, 2015), which gains supporters and media prominence due to the potential for engagement of personal reports (Rodino-Colocino, 2014; Thrift, 2014; Dixon, 2014; Eagle, 2015), for memes (Thrift, 2014) and for the maintenance and creation of networks exchange (Kim, 2017).

Despite the limitations of this new model of activism - which is caused by trollings that can expose women to virtual retaliation and lynching (Dixon 2014; Ganzer, 2014) research has revealed that the democratic gains of these mobilizations break the barriers of online and extend to others spheres (Kim, 2017; Dixon, 2014), and may reach the governmental sphere in some cases (Orlandini, 2019).

De Vuyst (2020) notes in her study on gender issues and the digital spaces of journalism that social media are a great ally for movements such as \#MeToo. These online protests provide alternative spaces where issues such as harassment and gender discrimination in newsrooms can be freely debated. Additionally, the use of social media has been said to be crucial for the professional status of journalists, for their credibility and reputation (Mourão, 2015). Women journalists make a critical use of social media and are aware of the impact that their virtual identity has on their audience and their profession, especially in regard to their position as women in a male-dominated world (WalshChilders, 1996; Duffy \& Pruchniewska, 2017) and to fight sexism, discrimination and harassment in journalism. Antunovic (2019) rightly points out a lack of understanding on the resources women journalists use to make these claims on social media, in particular, concerning their use of images and visual elements.

This shift from formats dominated by text or language to those putting the image at a cantered-stage has been referred to by Stöckl, Caple and Pflaeging (2020) as "imagecentricity". This does not mean that in social media the text is completely forgotten. Additionally, Stöckl, Caple and Pflaeging (2020) explain the shift towards imagecentricity on current media and propose some examples on Instagram where the main element is the image. Instagram is one of the most popular social media networks focused on the publication of audiovisual content (Laestadius, 2017). Posts must include an image or a short video - from 3 to 60 seconds - to which filters can be added to 
enhance them. The visual elements are combined with textual ones such as hashtags, comments, users' tags, geographic locations, or direct messages. Thus, Instagram's visual nature conveys meaning through visual elements and text is only used to provide context (Laestadius, 2017). Pearce et al. (2020) proposed the term 'visual vernacular' referring to common patterns that can be found in visual representations, and it comes from 'platform vernacular':

"A way of understanding how communication practices emerge within particular social network sites to congeal as genres. The norms, protocols, and user cultures of different social media platforms codify their own conversational forms and rhetoric tailored to their respective online contexts" (Gibbs et. al, 2016).

Martinec and Salway (2005) propose a new system, and propose in one of the possibilities that the interaction between image and text in social media posts are the creators of a "whole" with a meaning (Martinec \& Salway, 2005). The meaning we are referring to in this study is the self-representation of women journalists in relation to the hashtags \#DeixaElaTrabalhar and \#LasPeriodistasParamos. The creation of these social media posts and profiles where the user chooses every day what information to disclose allows the self-construction of the identity, the virtual identity (Boyd \& Heer, 2006). Thus, we argue here that the process of virtual identity construction is a way for female journalists to escape the control that the media has over the image.

\section{METHODOLOGY}

Following the literature review, this study sets the following main research question, which we aim at answering with two subquestions:

RQ: How do women journalists construct their identity on Instagram?

RQa: What gender-related problems concerning their profession do they protest about?

RQb: What are the common visual vernaculars on women journalists' Instagram posts? 
The study relies on Critical Discourse Analysis (CDA) as the analytical framework from which it is situated to answer the research questions posed. According to Van-Dijk (2017, p. 204), it is not a method but a critical perspective that "studies the way in which the abuse of power and social inequality is represented in the discourse". In other words, CDA focuses on the social and political contexts. The same author also stresses that many of the methods within the humanities and social sciences can be applied to carry out CDA. In our study, the documentary image interpretation (Bohnsack, 2008) is the selected method to analyse the Instagram posts in relation to the female journalists' collectives in the first place. It consists of a system built to help researcher's interpreting the images at the time that they fill the aims of the study. Our procedure, which has been developed following Bohnsack's (2008) dimensions of meaning and interpretation and Barthes' (1982) ideas on the rhetoric of the image, includes the following layers of identification: firstly, the pre-iconographic level to identify common visual vernaculars (motifs, phenomena, objects, and subjects); second, the iconographic level to describe what is being represented in the image from a connotative perspective (identify activities and plots); third, we look at the formal composition, including perspective, angle and composition; fourth, the iconological-iconic level to identify the position of the image producer, on a more subjective matter; and, finally, the accompanying text.

In order to answer the proposed research questions, we used a combination of visual and textual qualitative content analysis, following Fairclough's (1995a; 1995b) approach to Critical Discourse Analysis (CDA) and Barthes' (1968) semiotic analysis to identify the common image vernaculars (Wetzstein, 2017; Pearce et al. 2018) as well as the main topics addressed by the female journalists on their Instagram posts. The critical analysis focuses, according to Fairclough (1995a, p. 62), "at different levels of abstraction from the particular event: it may involve its more immediate situational context, the wider context of institutional practices the event is embedded within, or the yet wider frame of the society and culture". Furthermore, Fairclough (1995b) defines the process' phases as, firstly, examining the representation of individuals and processes or events in clauses. Then, we consider the whole organization of these clauses into a coherently structured whole. Another variable is that the analysis can focus on just a selected few 
features or many simultaneously, depending on the amount of material and desired analysis detail (Fairclough, 2003). From Barthes (1968), we take the approach of his system of significance, signifying unities of discourse (Barthes, 1968), and the analysis of the signs into two, the verbal and non-verbal signs. Verbal signs are the texts on the subtitles and the images (like posters), and the non-verbal signs are in the images of the posts. We used the sense of levels of signification with the concepts of denotation, being it the basic meaning of visual signs (Bouzida, 2014) and connotation, the interaction between the sign meeting the feelings or emotions of their users and their cultural values (Fiske, 1990).

The analysed material only includes still images within Instagram's hashtags \#DeixaElaTrabalhar (more than $14.8 \mathrm{~K}$ posts) and \#LasPeriodistasParamos (more than 2.000 posts). The hashtags represent two female journalists collectives consolidated in Brazil and in Spain, respectively. Within each hashtag, we used the following criteria to collect the sample materials: first, posts published in self-declared women journalists' accounts were taken into consideration; secondly, posts referring to the collectives; and, thirdly, posts containing still images (videos were excluded from this study). For publications with more than one image, all of them were analyzed independently; then, the accompanying text was included in the analysis. Since Instagram showed firstly some posts in the search that did not actually contain the hashtags, we had to control for that manually in order to select a post for the analysis material. The search of publications was set for the time frame between 2018 - coinciding with the aftermath of the \#MeToo movement - and 2021. This approach of material selection resulted in a collection of 90 Instagram images.

CDA helps us to show how women journalists discursively construct the hashtags \#DeixaElaTrabalhar and \#LasPeriodistasParamos as well as their own discourse on Instagram. The analysis focuses on several features to have a complete and comprehensive view of the hashtags' posts: the Documentary Image Interpretation (Bohnsack, 2008) and Barthes' (1982) ideas on the rhetoric of the image for the images of the posts, identifying visual vernaculars, connotative perspective, formal composition and the position of the image producer; Lexical Analysis for the subtitles, identifying the 
main themes via naming (users being the namers) and social actors referencing. For that, beyond examining if the prominent hashtags were inside the posts like previously said, we investigated other relevant hashtags (for example, \#TBT stands for "throwback Thursday", implying that the image is not from the current time of the post). Furthermore, we looked at the accounts tagged on the post to see if it changed any sense of the image and then we could interpret the whole message and search its connection to the image. We analyzed the posts in terms of a more extensive analysis of meaning from those features, deriving from the themes found in the literature review.

\section{RESULTS}

A first look at the images from the \#LasPeriodistasParamos shows similarities in the analysis material that mostly contains photographs taken during the $8 \mathrm{M}$ protests ( 30 images out of 45), portraying large crowds or groups. Over the years, the themes denounced in the publications, which we will explain below, remain constant without the appearance of new specific themes. In the case of the images with the \#DeixaElaTrabalhar, there is a diversity of themes, places, actions and elements which is observed at first glance. More than one-third of the images show women journalists mainly performing their work over the years (19 out of 45), while the rest is a combination of women in a sports field or personal portraits or selfies. Frequent use of the close-up and medium shot is observed.

The results are presented and discussed in greater detail below according to the research questions posed. Examples of the sample material are provided in the appendices.

\subsection{GENDER-RELATED ISSUES}

From our analysis, we identify the recurrent demands and denunciations on the posts regarding journalism gender-related issues to answer our RQa. Tables 1 and 2 in the appendices show a summary organized in different categories according to the main 
theme (feminism, role in journalism, newsroom, sexism and harassment, and empowerment).

In \#LasPeriodistasParamos, the analysis shows how female journalists denounce gender inequality in the profession at different levels. There are posts where journalists touch on the threats they suffer, for example, referring to situations of sexual harassment and how this type of situation does not usually happen to their male colleagues (Post 1). The lack of representation of women as professionals, as sources of information, as experts, and as opinion leaders also appear (verbally) in the posts (Posts 2). When, for example, female journalists are captured in their workspace, they are showing that their role is important to achieve inclusive and quality journalism (Post 3). They appeal to the media's responsibility for the representation of women globally and the situation of women in journalism. One example would be giving visibility to women in the third world, whose situation as women is aggravated by the situation of poverty in which they live, as well as to the work of the photojournalists who cover these stories (Post 4).

In the \#DeixaElaTrabalhar the female journalists denounce (visually and verbally) the discrimination they suffer when covering sports news events (Post 5) as well as the stereotypes concerning their physical appearance and clothing (Posts 6) and the physical and verbal harassment (Posts 7) they face in sports journalism. Within journalism reporting, women's competitions receive much less coverage and importance than men's competitions, as is reflected in the number of journalists assigned to cover these events (Posts 8 and 9). Thus, when the images capture women in their workplaces, handling the cameras or microphone in hand at stadiums, these are a way of claiming that their role is relevant (Post 10). In addition, other women practising sports are also represented, which indicates the collective's support for the struggle of women athletes in general beyond the media industry (Post 11).

\subsection{COMMON VERNACULARS}

In order to find common vernaculars, we adapted Gibbs et al. (2014) categorization and defined four different vernacular dimensions: the women and posts dimension shows two main patterns which are individual and collective photos; the events and places 
dimension reveals the tendency of female journalists to take photographs in similar locations for each collective; the events and elements dimension shows the existence of repeating elements makes it possible for each collective to build its own identity as an agent of social change, and the events and actions dimension describes common situations observed in the posts. These are summarized in Table 3 and explained in more detail in the following paragraphs.

Characterized by its connection to the March 8 feminist protest as noted at the beginning of this study, \#LasPeriodistasParamos contains a majority of group photos protesting for women's rights in the context of demonstrations in the streets of several Spanish cities (Posts 12 and 13). The colour purple as a symbol of the feminist movement is intertwined with bracelets with the word "press" and the microphone within a female symbol to reinforce the collective's message. When the images are not taken in the streets, TV sets and newsrooms are common (Post 14) representing the spaces where female journalists struggle to obtain an equal situation with their colleagues.

While the \#DeixaElaTrbalhar collective is mostly represented in sporting spaces such as media events, soccer fields, and large stadiums, which are places where crowds gather, the images focus on isolated individuals, usually the journalists themselves (Posts 15 and 16). The characteristic black background with white lettering that first appeared in the Brazilian journalists' protest video is printed on T-shirts worn by the journalists (Post 17). The journalists are captured doing their job, but also taking the position of players on the field (Post 18).

Table 1. Dimensions and common vernaculars within the hashtags

\begin{tabular}{|l|c|}
\hline \multicolumn{1}{|c|}{ Dimension } & \multicolumn{1}{c|}{ Common vernaculars examples } \\
\hline Women and posts & Collective, individual photos, others \\
\hline Event and places & $\begin{array}{r}\text { Streets, stage, sports field, stadium, TV set, radio studio, } \\
\text { landscape, at home, others }\end{array}$ \\
\hline Event and elements & $\begin{array}{r}\text { Purple colour, protest signs, bracelets, kids, balloons, } \\
\text { hearts, kerchiefs, sports t-shirts, balls, TV images, women } \\
\text { role models, microphones speakers, cameras, others }\end{array}$ \\
\hline Dement and actions & $\begin{array}{r}\text { clapping, horizon sight, victory sign, others } \\
\text { clation, sport event participation, smile, selfie, }\end{array}$ \\
\hline
\end{tabular}


Source: Own elaboration

\section{DISCUSSION}

In both hashtags, we see that women journalists in Brazil and Spain fight against stereotypes that simplify the role of women to a few characteristics (Hall, 2000) as well as against patriarchal structures (Walsh-Childers et al., 1996; Duffy \& Pruchniewska, 2017). What our study brings new to the topic is the way these professionals take control over their situation in the virtual sphere by using a repertoire of shared symbols and reporting journalism gender-related issues affecting them and their female colleagues from a first-person perspective - both visually and verbally. Furthermore, it is possible to point that the control of their situation is happening offline as well (at least through street protests).

The comprehensive analysis of the Instagram posts provides an overview of how women journalists portray themselves under the two collectives in terms of what kind of topics they talk about and which elements they use to insert themselves in the movement. In her study, on women journalists in Spain García-Mingo (2019) notes: "When writers say that the news is masculine, their accusation is double: first, the restricted and poor access those women have to information; and, second, the gender division in the journalistic workforce (Ginsburg et al., 2002)". A third factor would be the stereotyped image of women reproduced by the media that they denounce in the posts. For example, it was noted at beginning of this study that women journalists are kept apart from specific journalistic fields (Geertsema-Sligh, 2018). When women journalists finally access these fields, they face a hostile working environment instead based on gender stereotypes. In response to this situation, Brazilian women sports journalists choose to extol a "feminine" image in their posts to denounce that they are forced to "masculinize" themselves at work to go unnoticed and avoid sexist comments (Post 6). Thus, they seem to reproduce somehow the stereotyped image of women that other times women collectives' try to fight against.

As noted in the literature review, the information shared in social media accounts enables the construction of a new (virtual) identity (Boyd \& Heer, 2006) in relation to 
the world. Female journalists post with a non-violent protesting context (e.g. perceived in the smiles and relaxed environment) and show the community - both explicitly by portraying groups in the protests or implicitly using verbal messages of sisterhood. When female journalists use the \#DeixaElaTrabalhar or the \#LasPeriodistasPaaramos, they do so not only in relation to their profession but also to their private lives. They capture their mothers, their children, their friends (Post 19). One of the difficulties faced by women journalists is the reconciliation of work and personal life due to the irregularity of schedules and the high availability required of journalists (Melki and Mallat, 2019).

Fernandez, Castro-Martinez and Valcarcel (2019) refer to Castells when they point out that the rise of global communication has favoured the feminist movement. Based on the results of our study, this statement could be extended to collectives of women journalists who rely on social networks to disseminate their protests (always considering the limitations of the study). Cyberactivism is a form of resistance against hegemonic informative power (Castells, 2012, in Valcarcel, Fernández and Castro-Martinez, 2019) contributes a loudspeaker for the discourse of both collectives. The \#DeixaElaTrabalhar still engages social media users in 2021 with women outside the sports journalism field such as women referees, camerawomen, female athletes, and ultimately women in any profession adopting the hashtag. On the other hand, the \#LasPeriodistasParamos has broadened the goals that were first set (Bernal-Triviño y Sanz-Matos, 2019) and even gave rise to a formal organizational structure of women communicators in Spain (Fernández, Castro-Martinez and Valcarcel, 2019).

\section{CONCLUSION}

The purpose of the study was to explore how female journalists within the \#LasPeriodistasParamos and the \#DeixaElaTrabalhar construct their identity on Instagram in relation to their profession. Through the examination of the posts concerning the Brazilian and Spanish hashtags, it can be observed the broadness of female journalists' collectives. Despite sharing common goals, there exist factors that may influence their divergences such as the collective's origin, the scope of its demands, 
or the geographical context. Nevertheless, the online actions of these collectives helped out to improve the situation of women journalists offline. In every time more digitize world, social media activism remains for a community against the established power. Future research should look further into these aspects of the female journalists' collectives and their social media activism. Besides, the analysed posts often tag the social media accounts of the newsrooms they work for. It opens up a series of questions such as to what extend female journalists feel supported or coerced by the news media structures they work for in relation to demands for equality in journalism.

The generalizability of the results of this study is subjected to certain limitations. For instance, the study focuses only on Instagram and the results do not take into account the posts of the female journalists' collectives on other social media networks. Besides, it only analyses a part of the posts, namely still images. Finally, the sample collection was performed manually since Instagram does not allow the automatic collection of hashtags information. In spite of the limitations, this study contributes to increasing the understanding of how female journalists in Brazil and Spain engage online in two women journalists' collectives through their visual representation. Finally, with the results and outcomes of our study, we identified the opportunity to prepare a second research project. This project will use semi-structured in-depth interviews with the aim to further examining the experiences and perceptions of the women journalists involved in \#LasPeriodistasParamos and \#DeixaElaTrabalhar as well as answering some of the open questions that our study has raised.

\section{ACKNOWLEDGMENTS}

We would like to give special thanks to Luis Quesada-Baena, a fellow researcher who helped us with the original conception of our project. For all the support, we thank $\mathrm{Dr}$ Irmgard Wetzstein, Senior Lecturer at the Department of Communication at the University of Vienna (Austria), as well as to the MSc in Communication Sciences, motivating us to develop this project, which was initiated as part of an academic seminar on qualitative research methods. 


\section{REFERENCES}

Allan, S. (2019) Women and war photography. En/gendering alternative histories. In

Carter, S., Steiner, L., \& Allan, S. Journalism, Gender and Power (p. 312-330). London: Routledge.

Antunovic, D. (2019). "We wouldn't say it to their faces": online harassment, women sports journalists, and feminism. Feminist Media Studies, 19(3), 428-442. https://doi.org/10.1080/14680777.2018.1446454

Barker-Plummer, B., \& Barker-Plummer, D. (2017). Twitter as a Feminist Resource: \#YesAllWomen, Digital Platforms, and Discursive Social Change. In Earl, J. \& Rohlinger, D.A. (Ed.) Social Movements and Media (Studies in Media and Communications, Vol. 16) (pp. 91-118). Bingley: Emerald Publishing. https://doi.org/10.1108/S2050206020170000014010

Barthes, R. (1982). Lo obvio y lo obtuso. Imágenes, gestos, voces. Barcelona: Paidós Comunicación.

Barthes, R. (1968). Elements of semiology. New York: Hill and Wang.

Bennett, W. L., \& Segerberg, A. (2012). The logic of connective action. Information, Communication \& Society, 15(5), 739-768. https://doi.org/10.1080/1369118X.2012

Bernal-Triviño, A., \& Sanz-Martos, S. (2020). Las Periodistas Paramos in Spain: Professional, feminist Internet activism. European Journal of Communication, 35(4), 325-338. https://doi.org/10.1177/0267323120903687

Bohnsack, R. (2008). The Interpretation of Pictures and the Documentary Method. FQS Forum: Qualitative Social Research, 9(3), 296-321. https://doi.org/10.17169/fqs-

\subsubsection{1}

Bouzida, F. (2014). The semiology analysis in media studies: Roland Barthes Approach. In Proceedings of SOCIOINT14-International Conference on Social Sciences and Humanities (pp. 1001-1007). 
Boyd, D., \& Heer, J. (2006) Profiles as Conversation: Networked Identity Performance on Friendster. Proceedings of the 39th Annual Hawaii International Conference on System Sciences (HICSS'06). http://dx.doi.org/10.1109/HICSS.2006.394

Carter, C. (2019) Be cute, play with dolls, and stick to tea parties. In Carter, S., Steiner, L., \& Allan, S.(Ed.), Journalism, Gender and Power (pp. 236-250). London: Routledge.

Clark, R. (2014). NotBuyinglt: Hashtag Feminists Expand the Commercial Media Conversation. Feminist Media Studies, 14(6), 1108-1110.

https://doi.org/10.1080/14680777.2014.975473

Clark, R. (2016). "Hope in a hashtag": the discursive activism of \#WhylStayed. Feminist Media Studies, 16(5), 788-804. https://doi.org/10.1080/14680777.2016.1138235

Cole, K. K. (2015). "It's like she's eager to be verbally abused": Twitter, trolls, and (en)gendering disciplinary rhetoric. Feminist Media Studies, 15(2), 356-358.

De Vuyst, S. (2020). From bytes to backlash. Hacking Gender and Technology in Journalism. London: Routledge. https://doi.org/10.4324/9780429262029

Dixon, K. (2014). Feminist Online Identity: Analyzing the Presence of Hashtag Feminism. Journal of Arts and Humanities (JAH), 3(7), 34-40.

https://doi.org/10.18533/journal.v3i7.509

Duffy, B. E., \& Pruchniewska, U. (2017). Gender and self-enterprise in the social media age: a digital double bind. Information, Communication and Society, 20(6), 843-859. https://doi.org/10.1080/1369118X.2017.1291703

Eagle, R. B. (2015). Loitering, Lingering, Hashtagging: Women Reclaiming Public Space Via \#BoardtheBus, \#StopStreetHarassment, and the \#EverydaySexism Project. Feminist Media Studies, 15(2), 350-353. https://doi.org/10.1080/14680777.2015.1008748

Fairclough, N. (2003). Analysing discourse: Textual analysis for social research. London: Psychology Press.

Fairclough, N. (1995a). Critical Discourse Analysis. London: Longman. 
Fairclough, N. (1995b). Media Discourse. London: Arnold.

Fernández, E. G., Castro-Martinez, A., \& Valcarcel, A. S. (2019). Medios sociales y feminismo en la construcción de capital social: La red estatal de comunicadoras en España. Anàlisi, 61, 1-16. https://doi.org/10.5565/rev/analisi.3247

Fiske, J .(1990). Introduction to Communication Studies (2nd ed). New York: Routledge. Franks, S., \& Howells, L. (2019) Seeking women's expertise in the UK broadcast news media. In Carter, S., Steiner, L., \& Allan, S. Journalism, Gender and Power (pp. 49-61). London: Routledge

Freire, P. (2007). Education for Critical Consciousness. London: Continuum Publishing Company.

Ganzer, M. (2014). In Bed With the Trolls. Feminist Media Studies, 14(6), 1098-1100. https://doi.org/10.1080/14680777.2014.975441

García-Mingo, E. (2019). Women Journalists' Careers in Spain: The Case of War Correspondents. Comparative Sociology, 18(3), 302-326.

https://doi.org/10.1163/15691330-12341498

Geertsema-Sligh, M. (2018). Gender Issues in News Coverage. The International Encyclopedia of Journalism Studies (pp. 1-8). Wiley. https://doi.org/10.1002/9781118841570.iejs0162

Gibbs, M., Meese, J., Arnold, M., Nansen, B., \& Carter, M. (2015). \#Funeral and Instagram: death, social media, and platform vernacular. Information, Communication \& Society, 18(3), 255-268. https://doi.org/10.1080/1369118X.2014.987152

Gill, R. (2003). From Sexual Objectification to Sexual Subjectification: The Resexualisation of Women's Bodies in the Media. Feminist Media Studies, 3(1), 100-106.

https://doi.org/10.1080/1468077032000080158

Gillespie, T. (2010). The politics of 'platforms.' New Media \& Society, 12(3), 347-364. https://doi.org/10.1177/1461444809342738 
Gillespie, T. (2018a). Regulation of and by platforms. In: Burgess, J.; Marwick, A. \& Poell, T. The SAGE handbook of social media (pp. 254-278). London: SAGE Publications Ltd. https://www.doi.org/10.4135/9781473984066.n15

Gillespie, T. (2018b). Custodians of the Internet: Platforms, Content Moderation, and the Hidden Decisions That Shape Social Media. New Haven: Yale University Press.

Hall, S. (2000). Cultural Identity and Cinematic Representation. In. Stam, R. \& Miller, T. (ed.), Film and Theory: An Anthology. Oxford: Blackwell.

Hanitzsch, T., \& Hanusch, F. (2012). Does gender determine journalists' professional views? A reassessment based on cross-national evidence. European Journal of Communication, 27(3), 257-277. https://doi.org/10.1177/0267323112454804

Hopke, J. E. (2015). Hashtagging Politics: Transnational Anti-Fracking Movement Twitter Practices. Social Media + Society, 1(2).

https://doi.org/10.1177/2056305115605521

Kim, J. (2017). \#iamafeminist as the "mother tag": feminist identification and activism against misogyny on Twitter in South Korea. Feminist Media Studies, 17(5), 804-820. https://doi.org/10.1080/14680777.2017.1283343

Khoja-Moolji, S. (2015). Becoming an "Intimate Publics": Exploring the Affective Intensities of Hashtag Feminism. Feminist Media Studies, 15(2), 347-350. https://doi.org/10.1080/14680777.2015.1008747

Laestadius, L. (2017). Instagram. In Sloan, L., \& Quan-Haase, A. (Ed.), The SAGE Handbook of Social Media Research Methods (pp. 573-592). London: SAGE. Langman, L., \& Morris, D. (2003). Internet mediation: a theory of alternative globalization movements. Department of Sociology, Loyola University of Chicago, USA. Martinec, R., \& Salway, A. (2005). A system for image-text relations in new (and old) media. Visual Communication, 4(3), 337-371. https://doi.org/10.1177/1470357205055928 
Matos, C. (2017). New Brazilian feminisms and online networks: Cyberfeminism, protest and the female 'Arab Spring.' International Sociology, 32(3), 417-434. https://doi.org/10.1177/0268580917694971

McRobbie, A. (2004). Post-feminism and popular culture. In Feminist Media Studies, 4(3), 255-264. https://doi.org/10.1080/1468077042000309937

Melki, J., \& Mallat, S. (2019) When Arab women (and men) speak. In Carter, S., Steiner, L., \& Allan, S. (ed.), Journalism, Gender and Power (pp. 33-48). London: Routledge.

Mourão, R. R. (2015). The boys on the timeline: Political journalists' use of Twitter for building interpretive communities. Journalism, 16(8), 1107-1123.

https://doi.org/10.1177/1464884914552268

Pearce, W., Özkula, S. M., Greene, A. K., Teeling, L., Bansard, J. S., Omena, J. J., \& Rabello, E. T. (2020). Visual cross-platform analysis: digital methods to research social media images. Information, Communication \& Society, 23(2), 161-180.

https://doi.org/10.1080/1369118X.2018.1486871

Orlandini, M. (2019). Ativismo de sofá ou participação política? Os processos de politização do ativismo por hashtag. Mediação, 22(29), 135-151.

Ramires, L. (2020). Mulheres jornalistas esportivas e mercado de trabalho: quem (não) as deixa trabalhar? Revista Katálysis, 23(3), 501-509. https://doi.org/10.1590/198202592020v23n3p501

Rappaport, J. (1987). Terms of empowerment/exemplars of prevention: Toward a theory for community psychology. American journal of community psychology, 15(2), 121-148. https://doi.org/10.1007/BF00919275

Rappaport, J. (1995). Empowerment meets narrative: Listening to stories and creating settings. American journal of community psychology, 23(5).

https://doi.org/10.1007/BF02506992 
Reporters Without Borders (2020). Sexism's toll on journalism. Retrieved from https://rsf.org/sites/default/files/sexisms_toll_on_journalism.pdf

Ross, K., \& Padovani, C. (2019). Getting to the top. Women and decisión-making in European news industries. In Carter, S., Steiner, L., \& Allan, S. Journalism, Gender and Power (pp. 3-17). London: Routledge.

Rodino-Colocino, M. (2014). \#YesAllWomen: Intersectional Mobilization Against Sexual Assault is Radical (Again). Feminist Media Studies, 14(6), 1113-1115.

https://doi.org/10.1080/14680777.2014.975475

Ruoho, I., \& Torkkola, S. (2018). Journalism and Gender. Toward a Multidimensional Approach. Nordicom Review, 39(1), 67-79. https://doi.org/10.2478/nor-2018-0002

Shaw, A. (2016). Gendered Representations in Hawai'i's Anti-Gmo Activism. Feminist Review, 114(1), 48-71. https://doi.org/10.1057/s41305-016-0019-6

Shor, E., van de Rijt, A., Miltsov, A., Kulkarni, V., \& Skiena, S. (2015). A Paper Ceiling: Explaining the Persistent Underrepresentation of Women in Printed News. American Sociological Review, 80(5), 960-984. https://doi.org/10.1177/0003122415596999 Sarikakis, K., \& Nguyen, E. T. (2009). The trouble with gender: media policy and gender mainstreaming in the European Union. Journal of European Integration, 31(2), 201-216. https://doi.org/10.1080/07036330802642771

Steiner, L. (2019). Gender, sex, and newsroom culture. In Wahl-Jorgensen, K, \& Hanitzsch, T. (ed.), The Handbook of Journalism Studies (pp. 452-468). London: Routledge. https://doi.org/10.4324/9781315167497-29

Stöckl, H., Caple, H., \& Pflaeging, J. (2020). Shifts toward Image-Centricity in Contemporary Multimodal Practices. In Stöckl, H., Caple, H., \& Pflaeging, J. (ed.), Shifts toward Image-Centricity in Contemporary Multimodal Practices (pp. 1-16). London: Routledge. https://doi.org/10.4324/9780429487965-1 
Thrift, S. C. (2014). \#YesAllWomen as Feminist Meme Event. Feminist Media Studies, 14(6), 1090-1092. https://doi.org/10.1080/14680777.2014.975421

Valcarcel, A. S., Fernández, E. G., \& Castro-Martinez, A. (2019). The collective cyberactivist action of "Las periodistas paramos" for the feminist strike of 8M in Spain. Comunicación y Sociedad, e7287. https://doi.org/10.32870/CYS.V2019I0.7287

Van Dijck, J. (2013). The Culture of Connectivity. Oxford: Oxford University Press. https://doi.org/10.1093/acprof:oso/9780199970773.001.0001

Van-Dijk, T.A. (2017). Análisis Crítico del Discurso. Revista Austral de Ciencias Sociales, 30, 203-222. https://doi.org/10.4206/rev.austral.cienc.soc.2016.n30-10

Yang, G. (2016). Narrative Agency in Hashtag Activism: The Case of \#BlackLivesMatter. Media and Communication, 4(4), 13-17. https://doi.org/10.17645/mac.v4i4.692

Walsh-Childers, K., Chance, J., \& Herzog, K. (1996). Sexual Harassment of Women Journalists. Journalism \& Mass Communication Quarterly, 73(3), 559-581. https://doi.org/10.1177/107769909607300305

Wetzstein, I. (2017). The Visual Discourse of Protest Movements on Twitter: The Case of Hong Kong 2014. Media and Communication, 5(4), 26-36.

http://dx.doi.org/10.17645/mac.v5i4.1020 


\section{APPENDICES}

Table 2. Journalism gender-related issues mentioned in \#LasPeriodistasParamos

\begin{tabular}{|c|c|c|}
\hline Main topic & Connotations & $\begin{array}{c}\text { Verbal and non-verbal signs } \\
\text { examples }\end{array}$ \\
\hline Feminism & $\begin{array}{l}\text { Cultural, social, and economic problems } \\
\text { faced by all women affect women } \\
\text { journalists in their profession } \\
\text { Women rights: Changes at the } \\
\text { public/legal required }\end{array}$ & $\begin{array}{l}\text { A generalized use of \#8M, } \\
\text { \#Feminism. "Without feminism } \\
\text { there is no journalism" } \\
\text { \#OurRightsAreNotNegociable }\end{array}$ \\
\hline Role in journalism & $\begin{array}{l}\text { Lack of representation as professionals, } \\
\text { as sources, as experts, as opinion } \\
\text { leaders; demand for real equality with } \\
\text { their male colleagues }\end{array}$ & $\begin{array}{c}\text { "For a journalism where women } \\
\text { play a relevant role" }\end{array}$ \\
\hline Newsroom & $\begin{array}{l}\text { Obstacles to women career } \\
\text { development; overcome physical } \\
\text { stereotypes } \\
\text { Lack of reporting about feminist issues; } \\
\text { biased framing of victims of assault }\end{array}$ & $\begin{array}{l}\text { "I have a big bump and I am } \\
\text { doing TV" } \\
\text { "For a journalism that doesn't } \\
\text { blame women killings on women } \\
\text { victims themselves" }\end{array}$ \\
\hline Sexism, harassment & $\begin{array}{l}\text { Sexist comments, discriminatory } \\
\text { behaviour in the profession } \\
\text { Physical assaults from sources, violence, } \\
\text { lack of respect, fear to do their job }\end{array}$ & $\begin{array}{l}\text { "No interview questions that } \\
\text { would never be asked to a male" } \\
\text { "Do not touch a women } \\
\text { journalist there where you } \\
\text { wouldn't touch her male } \\
\text { colleague" }\end{array}$ \\
\hline Empowerment & $\begin{array}{l}\text { Prospects: Long way to achieve } \\
\text { equality, day-to-day actions required, } \\
\text { demands for public awareness of } \\
\text { violence and sexism }\end{array}$ & $\begin{array}{l}\text { "We wish that this (the } \\
\text { movement) doesn't stop after } \\
\text { this protest" }\end{array}$ \\
\hline
\end{tabular}

Source: Own elaboration 
Table 3. Journalism gender-related issues mentioned in \#DeixaElaTrabalhar

\begin{tabular}{|c|c|c|}
\hline Main topic & Connotations & $\begin{array}{l}\text { Verbal and non-verbal signs } \\
\text { examples }\end{array}$ \\
\hline Feminism & $\begin{array}{l}\text { Labour inequalities, low representation, } \\
\text { entry obstacles, assaults and } \\
\text { discrimination, difficulty to balance } \\
\text { family/work faced in other professions } \\
\text { are also encountered in journalism }\end{array}$ & $\begin{array}{c}\text { "we are soccer fans, players, } \\
\text { journalists, sportswomen, } \\
\text { lawyers, judges, publicists, } \\
\text { housewives, directors, teachers, } \\
\text { politicians, and above all } \\
\text { WOMEN!" }\end{array}$ \\
\hline Role in journalism & $\begin{array}{l}\text { Stereotypes and discrimination; women } \\
\text { journalists unrepresented in sports } \\
\text { newsrooms; lack of coverage of women } \\
\text { sports events; sexist comments }\end{array}$ & $\begin{array}{l}\text { Photo 1: } 2 \text { male and } 2 \text { women } \\
\text { teams for covering women's } \\
\text { soccer. Photo 2: } 23 \text { male and } 3 \\
\text { women for covering men's soccer }\end{array}$ \\
\hline Newsroom & $\begin{array}{l}\text { Male-dominated profession; obstacles } \\
\text { placed by male colleagues; competitive } \\
\text { and uncomfortable environment; } \\
\text { rejection; need to hide femininity }\end{array}$ & $\begin{array}{l}\text { "We are here to conquer the } \\
\text { spaces that by right are ours, and } \\
\text { that someone dare to say they } \\
\text { were not ours", "I had to try not } \\
\text { to be noticed in a typically male } \\
\text { environment to avoid comments" }\end{array}$ \\
\hline Sexism, harassment & $\begin{array}{c}\text { Stop physical assaults, abuse, and } \\
\text { discrimination; normalization of (online) } \\
\text { harassment; lack of respect }\end{array}$ & $\begin{array}{l}\text { "I am sad to see that the assault } \\
\text { was normalized...and the people } \\
\text { supporting the aggressive } \\
\text { comments of those cowards on } \\
\text { the Internet" }\end{array}$ \\
\hline Empowerment & $\begin{array}{l}\text { Sisterhood; visualization of women in } \\
\text { journalism }\end{array}$ & "If you shine, we shine with you" \\
\hline
\end{tabular}

Source: Own elaboration

All the following post examples are public and for free access:

Post 1: https://www.instagram.com/p/B9emqXypEIU/?utm_medium=copy_link

Post 2: https://www.instagram.com/p/B9eblZoJ_Fd/?utm_medium=copy_link

Post 3: https://www.instagram.com/p/ButTltOFNnF/?utm_medium=copy_link

Post 4: https://www.instagram.com/p/BgE791Fg8h9/

Post 5: https://www.instagram.com/p/CKzzljunuEz/

Post 6: https://www.instagram.com/p/B9iBI7EAfza/

Post 7: https://www.instagram.com/p/CHHKLdInndJ/?utm_medium=copy_link 
Post 8: https://www.instagram.com/p/B21ZMO-AXI5/?utm_medium=copy_link

Post 9: https://www.instagram.com/p/B21ZMO-AXI5/?utm_medium=copy_link

Post 10: https://www.instagram.com/p/BythYjQA_US/?utm_medium=copy_link

Post 11: https://www.instagram.com/p/B9eoz0sB4gR/?utm_medium=copy_link

Post 12: https://www.instagram.com/p/BgFGzDuFtXv/

Post 13: https://www.instagram.com/p/BgEA4Vmgvwt/?utm_medium=copy_link

Post 14: https://www.instagram.com/p/B9f_UhHHZKI/

Post 15: https://www.instagram.com/p/COVTM7isfPu/

Post 16: https://www.instagram.com/p/CGobXKfhg6F/?utm_medium=copy_link

Post 17: https://www.instagram.com/p/ByyV8DJg4BR/?utm_medium=copy_link

Post 18: https://www.instagram.com/p/CO1pDpthD9M/

Post 19: https://www.instagram.com/p/BgDwDHQgMuO/ 